\title{
PRINCÍPIO COMPÉTENCE-COMPÉTENCE: AMPLITUDE, LIMITAÇÕES E APLICABILIDADE NA ARBITRAGEM COMERCIAL
}

Ricardo Stersi dos Santos

Professor da Universidade Federal de Santa Catarina (UFSC), nos cursos de Graduação, Mestrado e Doutorado. Mestre e Doutor em Direito pela UFSC. Pós-doutorado na UFPE (2011-2012).

Rafael Peteffi da Silva Professor da Universidade Federal de Santa Catarina (UFSC), nos cursos de Graduação, Mestrado e Doutorado. Doutor em Direito Civil (USP). Árbitro e Parecerista.

\section{Resumo}

O presente artigo visa apresentar as melhores soluçóes jurídicas para os casos em que existe dúvida razoável sobre o alcance da cláusula arbitral. O princípio CompétenceCompétence estabelece a prerrogativa dos árbitros para realizar a análise inicial sobre a sua própria competência e está positivado no art. $8^{\circ}$ da lei de arbitragem brasileira. Apesar disso, existem algumas ocasióes em que o princípio Compétence-Compétence é relativizado, ora por força da própria legislação arbitral, ora por força de uma jurisprudência mais protetiva, em algumas searas, da jurisdição estatal. Em relação à seara empresarial, ao contrário, a Jurisprudência apresenta solidez ao dar máxima eficácia ao princípio da Compétence-Compétence.

\section{Palavras-chave}

Princípio Compétence-Compétence; Jurisdição; Arbitragem Comercial.

\section{Abstract}

This article aims to present the best legal solutions to cases where there is reasonable doubt about the scope of the arbitration clause. The principle of Compétence - Compétence establishes the prerogative of the arbitrators to conduct the initial analysis of its jurisdiction and is observed in art. $8^{\circ}$ of the Brazilian arbitration law. Nevertheless, there are some occasions when the principle of Compétence-Competence is relativized, 
sometimes by the arbitration law, sometimes by legal precedentes, wich enforces, in some areas, the state jurisdiction. Regarding corporate law, instead, the Courts have strength to give maximum effect to the principle of Compétence - Compétence .

\section{Key words}

Principle of Compétence; Compétence; Jurisdiction; Commercial Arbitration.

\section{Introdução}

A utilização da arbitragem como meio adequado de resolução de conflitos mostra-se uma inegável realidade em terras brasileiras. Apesar do principal marco legislativo do país, a lei 9.307 de 1996, ser ainda recente - além de ter a sua constitucionalidade confirmada pelo Supremo Tribunal Federal somente em 2001 - o Brasil já se coloca entre os principais países no cenário da arbitragem internacional e a jurisprudência nacional, na grande maioria das situaçôes, respalda a eficácia das decisóes arbitrais (TIBURCIO, 2012, p. 75 -76).

São muitas as causas que motivam a popularização da arbitragem no Brasil. Entre os motivos considerados fundamentais para o sucesso do instituto cita-se: i. a possibilidade de escolha do árbitro, permitindo que as partes centrem a escolha em árbitros com grande experiência e capacidade técnica para elucidar o conflito em questáo, ii. a possibilidade de determinação das regras aplicáveis ao procedimento e ao mérito do litígio, iii. a celeridade, especialmente importante em tempos de Poder Judiciário extremamente moroso, iv. o sigilo (SANTOS, 2004, p.30).

O presente artigo debruça-se sobre um princípio muito caro á comunidade arbitral: o princípio Compétence-Compétence. Esse princípio está positivado no parágrafo único do artigo $8^{\circ}$ da Lei de Arbitragem brasileira e garante a competência do árbitro para decidir acerca da existência, validade e eficácia da convenção de arbitragem. Portanto, existindo eventual dúvida sobre a extensão da jurisdição transferida para os árbitros, por exemplo, são eles próprios que deverão julgar a respeito da sua competência para o enfrentamento inicial da matéria, sem excluir futura decisão por parte do Poder Judiciário, em eventual ação anulatória. A primazia temporal na análise da sua própria competência, portanto, caberia aos próprios árbitros.

Em seu segundo capítulo, este trabalho desenvolve as características principais e a extensão do princípio Compétence-Compétence, relacionando-o ao que a doutrina costuma denominar de duplo efeito da celebração da convenção de arbitragem.

Mesmo entendendo que o aludido princípio representa ponto nodal para o desenvolvimento da arbitragem, o terceiro capítulo demonstra que ele pode ser relativizado em 
algumas situaçóes. Destarte, a própria lei brasileira dispóe sobre casos esporádicos em que o juiz realizará a análise da validade e eficácia da convenção de arbitragem em primeiro lugar. Também será discutido, ainda nesse capitulo, os chamados "casos sensíveis", nos quais o Poder Judiciário, normalmente em função da matéria envolvida, acaba por decidir sobre a (in)competência do árbitro para julgar o litígio antes que este possa se manifestar.

Apesar dos casos de possível relativização do princípio Compétence-Compétence verificados no capítulo terceiro, o último capítulo do presente trabalho mostrará que a jurisprudência brasileira respalda a primazia dos árbitros no enfrentamento da causa, mormente em matéria empresarial. Uma decisão do Tribunal de Justiça do Rio de Janeiro, exatamente por ser extremamente recente, servirá de exemplo principal para ilustrar a tendência do Poder Judiciário brasileiro em relação ao princípio em comento.

\section{Arbitragem Comercial e o Princípio Compétence-Compétence}

O conceito de arbitragem é estabelecido na doutrina a partir das características centrais que identificam o instituto. Toma-se como arbitragem o mecanismo de resolução de conflitos em que as partes, por meio de convenção privada, escolhem a uma ou mais pessoas, designado(s) árbitro(s) e lhe(s) atribui jurisdição para decidir os conflitos já surgidos ou que possam vir a surgir decorrentes de relaçáo contratual ou extracontratual existente entre as partes.

Conforme Carmona (2009, p. 31) "Trata-se de mecanismo privado de solução de litígios, por meio do qual um terceiro, escolhido pelos litigantes, impóe sua decisão, que deverá ser cumprida pelas partes".

A propagação da utilização da arbitragem na atualidade está associada principalmente aos conflitos comerciais, pouco importando se por meio de tribunais arbitrais "ad hoc" ou por meio de arbitragens administradas por instituiçôes de arbitragem (institucional).

Ilustrando o incremento no uso da arbitragem comercial e conforme os dados fornecidos pela Câmara de Comércio Internacional de Paris, as arbitragens administradas pela instituição passaram de 529 em 1999 para 791 em 2014, sendo que em 23,5\% dos casos novos os valores envolvidos eram superiores a um milhão de dólares. ${ }^{1}$

No Brasil o crescimento também é exponencial nas arbitragens comerciais institucionais. De acordo com Lemes (2014) em seis das principais câmaras arbitrais no Brasil, foram 603 os casos novos registrados no período de 2010 a 2013 sendo que as principais matérias de conflito submetidas à arbitragem são: societária, construção civil e energia. ${ }^{2}$

1 Disponível em: http://www.iccwbo.org/Products-and-Services/Arbitration-and-ADR/Arbitration/ Introduction-to-ICC-Arbitration/Statistics/. Acesso em 09/05/2015.

2 Disponível em: http://www.conjur.com.br/2014-abr-10/selma-lemes-numeros-mostram-maioraceitacao-arbitragem-brasil. Acesso em 09/05/2015. 
A partir de Redfern e Hunter (1999, p. 18) pode-se apontar que a arbitragem comercial é aquela em que a solução dos conflitos decorrentes do curso normal dos negócios celebrados por dois ou mais comerciantes é dirimido por árbitro.

Para Guerreiro (1993, p. 125-6):

No direito brasileiro, vale a opinião de Fábio Konder Comparato de que, inexistindo, no Código Comercial, uma definição geral do que deva ser considerado contrato mercantil, e não havendo expressa indicação de um critério distintivo específico [...], deve-se admitir que a comercialidade do contrato resulta de sua inserção no fluxo da atividade empresarial ou mercancia.

A tipificação da relação comercial é relevante para diferencia-la de outras relaçóes que não o são de fato. Entretanto não é toda matéria comercial que é suscetível de ser resolvida por meio de arbitragem. No Brasil a limitação geral sobre a arbitrabilidade objetiva (aplicável também aos conflitos comerciais) encontra-se prevista no artigo $1^{\circ}$ da Lei no 9307/96, admitindo a arbitragem para os conflitos que versam sobre direitos patrimoniais disponíveis.

Como meio jurisdicional de resoluçáo de conflitos a arbitragem se fundamenta em certos princípios como o Compétence-Compétence.

O princípio Compétence-Compétence estabelece uma "hierarquia cronológica" entre a jurisdição do árbitro e a dos órgãos do Poder Judiciário no que diz respeito ao julgamento da competência outorgada, pelas partes, na convenção de arbitragem. Cabe, assim, ao árbitro, decidir por primeiro as questóes atinentes a existência e a validade da convençáo de arbitragem bem como interpretar a extensão dos próprios poderes fixados na convenção.

De acordo com Redfern e Hunter (1999, p. 264) "É geralmente aceito que o tribunal arbitral tem poder de investigar sua própria jurisdição. Este é um poder inerente na nomeação de um tribunal arbitral [...]". ${ }^{3}$

Conforme Fluja (2004, p. 810):

De este principio se deriva, como núcleo básico, que el árbitro tiene la facultad de ser el primero en analizar y determinar si la controvérsia que se somete entra en el ámbito del convenio arbitral correspondiente [...]. Y como núcleo básico también, se deriva que el árbitro puede analizar la existência y validez del convenio porque si él no podría conocer de ningún asunto, incluso aunque ese asunto esté incluído en el âmbito del convenio y dentro de ló pactado por las partes.

3 "It is generally accepted that an arbitral tribunal has power to investigate its own jurisdiction. This is a power inherent in the appointment of an arbitral tribunal [...]. 
A partir da aplicação do princípio Compétence-Compétence fica estabelecido, como regra, que a ordem cronológica da apreciação jurisdicional se inicia com o árbitro, cabendo ao mesmo julgar, por primeiro, os limites da sua própria jurisdição. A judicialização da questão só ocorre num segundo momento, após o prolatação da decisão do árbitro sobre a sua jurisdição, e por meio dos procedimentos específicos previstos na lei aplicável (no Brasil o artigo 33 da Lei 9307/96).

O princípio Compétence-Compétence é um princípio que serve à jurisdição. Estabelece uma ideia geral para a convivência entre a jurisdição dos árbitros e a dos órgãos do Poder Judiciário evitando, na medida do possível, o conflito positivo de competências que ocorre quando o árbitro (fundamentado na aplicação do princípio) e o Poder Judiciário (negando a aplicação do princípio) se reconhecem competentes para julgar certa questão litigiosa.

Ao estabelecer um enunciado geral sobre a jurisdição competente para julgar a matéria, o princípio Compétence-Compétence se conecta a outros princípios para garantir a segurança jurídica e a efetivação da jurisdição nos conflitos em que as partes tenham escolhido resolver por meio de arbitragem.

Como indica Pitombo (2007, p. 327) a ignorância ao princípio Compétence-Compétence:

[...] seria atentar náo somente contra a autonomia da vontade das partes (presumivelmente livre e licitamente manifestada), mas também contra a presunçáo de idoneidade da própria arbitragem, retirando daqueles que a elegeram toda a segurança jurídica.

No Brasil autores como Carmona (2009, 175-182), Rechsteiner (2001, p. 64-69), entre tantos outros, reconhecem que o princípio Compétence-Compétence encontra-se devidamente contemplado no artigo $8^{\circ}$, parágrafo único da Lei 9307/96, autorizando o árbitro a decidir, de ofício ou por provocação de uma das partes, sobre a sua própria jurisdição.

O artigo $8^{\circ}$ da Lei 9307/96 foi inspirado no artigo 16, item 1, da Lei Modelo da Uncitral para arbitragem comercial internacional, elaborada em 1985 e alterada em 2006. No Brasil o caput do artigo $8^{\circ}$ trata da autonomia da cláusula compromissória em relaçáo ao contrato principal e o parágrafo único contempla o princípio Compétence-Compétence. Tal princípio se associa aos efeitos designados na doutrina como o duplo efeito da celebração de convenção de arbitragem válida.

Para Carmona (2009, p. 79), o duplo efeito da convenção de arbitragem válida:

[...] vincula as partes no que se refere a litígios atuais ou futuros, obrigando-as reciprocamente à submissão ao juízo arbitral; como pacto processual, 
seus objetivos são os de derrogar a jurisdição estatal, submetendo as partes à jurisdição dos árbitros. Portanto, basta a convenção de arbitragem (cláusula ou compromisso) para afastar a competência do juiz togado, sendo irrelevante estar ou não instaurado o juízo arbitral (art. 19).

O duplo efeito se traduziria assim, por primeiro, no dever assumido pelas partes, na convençáo de arbitragem válida, de resolver todas as questóes relativas ao conflito instaurado entre as mesmas por meio do árbitro. $\mathrm{O}$ dever das partes de submeter tal conflito a arbitragem, portanto, vai para além das questóes de mérito, vinculadas aos direitos patrimoniais disponíveis previstos na convenção de arbitragem, e se estende também para as questóes prejudiciais à análise do mérito, relativas ao desenvolvimento regular e válido da arbitragem, nos limites da lei que regula a arbitragem.

Esse dever das partes se traduz no reconhecimento da jurisdição do árbitro para apreciar, por primeiro, todas as questóes decorrentes dos conflitos elencados na convenção de arbitragem, cabendo ao árbitro interpretar, por exemplo, se um determinado conflito submetido pelas partes encontra-se ou não contemplado na convenção de arbitragem.

Tais poderes são inerentes à jurisdição atribuída na convenção de arbitragem válida e deverão ser exercidos pelo árbitro nos limites estabelecidos na própria convenção e na lei aplicável à arbitragem.

No Brasil, os poderes se refletem, por exemplo: a) na aplicação do artigo 8o, parágrafo único, da Lei 9307/96 que reconhece a jurisdição do árbitro para decidir sobre a sua competência, podendo de ofício ou por provocação julgar as impugnaçóes relativas à existência e validade da convenção de arbitragem; b) na aplicação do artigo $22, \$ 4^{\circ}$, que estabelece a jurisdição do árbitro para decidir sobre a necessidade e a possibilidade de concessão de medidas de urgência (coercitivas ou cautelares) preparatórias ou incidentais ao processo arbitral; c) na aplicação do artigo 21, parágrafo único, que atribuí ao árbitro o poder de escolher as regras relativas ao processo e ao procedimento arbitral, caso as partes não o tenham feito na convenção de arbitragem, ou mesmo o de afastar as regras escolhidas pelas partes caso infrinjam a ordem pública; d) no poder implícito de escolher o direito aplicável ao mérito do conflito, caso as partes não o tenham feito na convenção de arbitragem e também de afastar a aplicação das regras eleitas pelas partes caso infrinjam a ordem pública; e) na aplicação do artigo 22, caput, que autoriza o árbitro a determinar de ofício a produçáo das provas que entender necessárias à formação do seu convencimento; f) na aplicação do artigo 15 e do artigo 20 que reconhecem a jurisdição do árbitro para apreciar as questões relativas a sua suspeição ou impedimento, além daquelas que digam respeito a existência e validade da convenção de arbitragem.

O segundo dos efeitos decorrentes da convenção de arbitragem válida é o afastamento da possibilidade do Poder Judiciário julgar o mérito dos conflitos indicados na 
própria convenção e que devem ser submetidos à arbitragem, nos limites da lei aplicável à arbitragem (matérias arbitráveis).

À luz do princípio Compétence-Compétence tem-se dois desdobramentos decorrentes do aludido efeito.

No primeiro, apenas o árbitro recebe jurisdição para decidir sobre o mérito dos conflitos indicados na convenção de arbitragem válida, desde que tais conflitos sejam arbitráveis, nos termos do artigo $1^{\circ}$ da Lei 9307/96.

No segundo dos desdobramentos, o árbitro recebe a jurisdição para, em ordem cronológica anterior aos órgãos do Poder Judiciário, conhecer dos aspectos processuais e materiais relativos à arbitragem, tais como a existência e a validade da convenção de arbitragem, a interpretação e a decisão sobre os poderes concedidos pelas partes na convenção de arbitragem e na lei aplicável à arbitragem, a verificação do preenchimento dos requisitos e a apreciação da possibilidade de concessão de tutelas de urgência, etc. Neste segundo desdobramento, a jurisdição dos órgãos do Poder Judiciário ocorrerá, em regra, após a apreciação da questão pelo árbitro, e a referida jurisdição ocorrerá nos termos e limites estabelecidos na ordem jurídica (procedimento previsto no artigo 33, com as matérias indicadas no artigo 32 da Lei 9307/96, além do procedimento de homologação de sentença arbitral estrangeira, nos casos de arbitragem cuja sentença foi proferida fora do território brasileiro).

A jurisdição dos órgãos do Poder Judiciário existe e deve ser exercida por provocação das partes desde que, em regra, respeite a ordem cronológica prevista (competência anterior do árbitro) e seja exercitada nos limites impostos pela ordem jurídica. Tal cronologia de competências é assegurada pela aplicação da exceção de convenção de arbitragem válida, que será oposta por uma das partes, perante o Poder Judiciário, quando a outra buscar, unilateralmente, subverter a ordem de competências e levar as questóes conflituosas que devem ser submetidas à arbitragem aos órgãos do Poder Judiciário.

\section{Doutrina e Jurisprudência que Relativizam a Aplicação do Princípio Com- pétence-Compétence}

São quatro as principais hipóteses em que a doutrina e/ou a jurisprudência apontam para uma relativização na aplicação do princípio Compétence-Compétence.

Na primeira das hipóteses, a própria lei 9307/96, no seu artigo 7º, estabelece situação em que a ordem cronológica para a apreciação dos limites jurisdicionais é invertida, cabendo aos órgãos do Poder Judiciário decidir, por primeiro, sobre questóes relativas à existência e validade da convenção de arbitragem e sobre a matéria objeto do conflito.

Conforme Lee (2002, p.98) corretamente expóe: 
Se o juiz recebe uma ação de execução de cláusula arbitral, cabe a ele analisar primeiramente a existência e a validade desta cláusula. Em seguida, em caso de desacordo das partes, o juiz redige o compromisso segundo as regras do direito positivo. Ora, o direito argentino, o brasileiro e o uruguaio colocam como condição do compromisso, entre outras, a especificação dos pontos litigiosos. Assim o juiz decide se o litígio é ou não arbitrável, e consequentemente, se os árbitros são ou não competentes para apreciar a controvérsia. Esta apreciação da competência do árbitro pelo juiz se opóe ao princípio "competência-competência”, e de uma certa maneira, o exclui.

Ao discorrer sobre o procedimento do artigo $7^{\circ}$, da lei 9307/96, aplicável principalmente para a situação de celebração, pelas partes, de cláusula compromissória vazia, Carmona (2009, p. 176) segue pela mesma linha de raciocínio e reconhece que o referido dispositivo legal se constitui numa relativização do princípio Compétence-Compétence. Para o referido autor:

A atribuição de poderes ao árbitro para regular seus próprios poderes, porém, resolve apenas parte do problema, pois, em algumas hipóteses, caberá ao juiz togado lidar com a questão da existência, validade e eficácia da convenção de arbitragem. Isso ocorrerá, como já se viu, nos casos do art. $7^{\circ}$ da Lei, e também quando o réu, citado para os termos da demanda, arguir exceção de compromisso [...]. (CARMONA, 2009, p. 176)

A segunda hipótese em que a aplicação do princípio Compétence-Compétence pode vir a ser relativizada ocorre quando os órgãos do Poder Judiciário tem a possibilidade de identificar, sem a necessidade de profunda dilação probatória ou esforço de interpretação da questão, que a matéria objeto do conflito não se encontra contida na matéria indicada pelas partes na convenção de arbitragem ou quando se trata de parte que manifestamente não consentiu na celebração de convenção de arbitragem.

Na terceira hipótese, a relativização do princípio Compétence-Compétence é admitida em razão da matéria objeto da convenção de arbitragem. Nas matérias reconhecidas como "sensíveis" existe, na doutrina e na jurisprudência, uma discussão sobre a possibilidade de tal relativização.

Redfern e Hunter (1999, p. 148-154) apontam algumas matérias tidas como "sensíveis" em relação a sua arbitrabilidade tais como questóes relativas a marcas e patentes, contratos que porventura atraiam a aplicação de legislação anti-truste e de competição comercial, contratos celebrados mediante suborno ou corrupção e alegaçóes de fraude contratual. Os autores reconhecem, entretanto, que a referida questão acaba por variar de Estado para Estado, de acordo com a legislação arbitral aplicável.

Ao discorrer sobre as matérias "sensíveis" nos países do Mercosul, Lee indica que: 
As matérias patrimoniais "sensíveis", ou seja, aquelas nas quais a disponibilidade dos direitos é incerta, e onde a ordem pública tem uma forte tendência a intervir, são o barômetro do liberalismo do país em questão de arbitragem. De fato quanto mais o país é reticente em relação à arbitragem, mais a arbitrabilidade destas matérias será restrita.[...] matérias como direito societário, a propriedade intelectual, o direito à concorrência, a falência, o direito do consumidor, não seriam a priori arbitráveis.

Nas decisóes de diversas cortes distintas, no Brasil, sobre a possibilidade de submeter certas matérias "sensíveis" à arbitragem, são identificados julgados que ora reconhecem a arbitrabilidade de tais matérias e que ora rejeitam a referida arbitrabilidade.

Por vezes a decisão que promove a rejeição da arbitrabilidade da matéria é tomada em ação judicial, perante os órgãos do Poder Judiciário que, ao decidir, por primeiro, sobre a questão da existência e da validade da convençáo de arbitragem (quanto a arbitrabilidade da matéria), age de forma a ignorar a aplicação do princípio CompeténceCompétence, ainda que o réu eventualmente tenha arguido, como questão preliminar e prejudicial, à existência de convenção de arbitragem válida e pleiteado pela extinção do processo judicial sem resolução de mérito. Tal quadro, no Brasil, ocorre, preferencialmente, quando a matéria submetida à arbitragem versa sobre relaçóes de consumo ou sobre os direitos decorrentes de relação individual de emprego.

Julgados recentes apontam para o reconhecimento de uma espécie de competência concorrente entre os órgãos do Poder Judiciário e os árbitros quando a matéria prevista na cláusula compromissória for relacionada às relaçóes de consumo.

Os consumidores, nos julgados relatados, ajuizaram ação judicial perante os órgãos do Poder Judiciário apesar de ter subscrito cláusulas compromissórias inseridas em contratos de adesáo. Uma vez citados, os fornecedores arguiram, como questáo preliminar, a exceção de convenção de arbitragem, requerendo ao juízo estatal a extinção do processo judicial sem resolução do mérito (ao alegar que a jurisdição sobre o conflito encontrava-se atribuída aos árbitros, em virtude da celebração entre as partes de cláusula arbitral válida). Relativizando o princípio Compétence-Compétence, os órgãos do Poder Judiciário ignoraram a cronologia de apreciação das questóes atinentes à existência e validade da cláusula arbitral e julgaram nulas as referidas cláusulas arbitrais, passando a decidir, posteriormente, o mérito do conflito. Neste sentido tem-se os seguintes julgados:

TJRS - Ag.Instr. no 70051678332 - 10ª Câmara Cível - Relator Jorge Alberto Schreiner Pestana - Agravante: Cativa Turismo Ltda - Agravado: Claudio Luis da Vinha Noronha - julgado em 28/02/2013 - votação unânime.

TJRJ - Ap. Cível no 0007525-03.2011.8.19.0209 - 26a Câmara Cível/ Consumidor - Relatora Ana Maria Pereira de Oliveira - Apelantes: 
Brookfield S/A e Josiane Faltz Barbosa - Apelados: os mesmos - julgado em 29/01/2015 - votação unânime.

TJRJ - Ap. Cível no 0026771-82.2011.8.19.0209 - 26a Câmara Cível/ Consumidor - Relator Marcos Antônio Ribeiro de Moura Brito - Apelante: Cyrela RJZ Gulf Empreendimentos Imobiliários SPE LTDA Apelados: Luiz Alberto Xavier Pinto e Roseli Martins Xavier Pinto - julgado em 15/01/2015 - votação unânime.

Além das questóes atinentes as relaçóes de consumo, outra matéria identificada como "sensível" no que tange a sua arbitrabilidade e que suscita, por vezes, a mesma relativização do princípio Compétence-Compétence, no Brasil, diz respeito aos dissídios individuais.

Existem decisóes dos tribunais nacionais que afastam totalmente a aplicação da cronologia de jurisdição estabelecida pelo princípio Compétence-Compétence. Nos referidos julgados são reconhecidos, de plano, pelos órgãos do Poder Judiciário, a nulidade da convenção de arbitragem celebrada entre empregado e empregador.

Os casos mais comuns, revelados pela jurisprudência, são as rescisóes de relaçóes de emprego realizadas por acordo entre as partes e levadas à homologaçáo de árbitros. O empregado, posteriormente à homologação pelo árbitro, e ao recebimento das verbas acordadas, ajuíza ação trabalhista exigindo certos direitos (e os seus efeitos materiais) que teria negociado e dado quitação no acordo.

A alegação fundamental trazida pelos autores das ações é que os direitos decorrentes da relação individual de trabalho não são suscetíveis de serem resolvidos por meio de arbitragem, visto se tratarem de direitos indisponíveis.

Os órgãos do Poder Judiciário tem, então, reconhecido a nulidade da sentença homologatória proferida pelo árbitro, bem como da convenção de arbitragem firmada pelas partes por se tratar de matéria não arbitrável.

O caso também pode se apresentar nas hipóteses em que se extingue a relação de emprego e o empregado vai aos órgãos do Poder Judiciário para pleitear os seus respectivos direitos decorrentes da referida relação. O empregador apresenta, como matéria preliminar da sua defesa, o pedido de extinção da ação trabalhista sem a resolução do mérito, em razão da existência de convenção de arbitragem válida celebrada entre as partes quando da celebração do contrato de trabalho.

A jurisprudência do Tribunal Superior do Trabalho tem se firmado no sentido de que, diante de convenção de arbitragem manifestamente nula, é possível decidir, de plano, sem aplicar o princípio Compétence-Compétence, visto que a matéria objeto do conflito se refere à interpretação e à aplicação de direitos indisponíveis e que a Constituição Brasileira autoriza, formalmente, apenas a arbitragem para dissídios coletivos. Nestes sentidos têm-se os julgados: 
TST - R.R. no 101900-60.2009.5.02.0024 - 7a Turma - Relator Claudio Mascarenhas Brandão - Recorrente: Associação dos Funcionários do Tribunal de Contas do Estado de São Paulo - Recorrido: Euclides Soares da Silva - julgado em 04/02/2015 - votação unânime.

TST - A.I.R.R. no 445-34.2012.5.01.0005 - 2a Turma - Relator José Roberto Freire Pimenta - Agravante: Sertrading (BR) Ltda - Agravada: Vanusa Moraes Pereira - julgado em 29/10/2014 - votaçáo unânime.

A quarta hipótese de relativização do princípio Compétence-Compétence, reconhecida na doutrina e na jurisprudência, ocorre quando qualquer das partes necessita da concessão de medida de urgência e haja a impossibilidade de instauração da arbitragem em prazo razoável (tais como nas situaçóes em que as partes celebraram cláusula compromissória vazia e não tenham apontado, previamente, o árbitro ou o procedimento para a sua escolha).

Lamy, Peteffi e Santos (2012, p.327) reconhecem que nestes casos existe uma jurisdição extraordinária e provisória dos órgãos do Poder Judiciário, invertendo-se a cronologia de jurisdição entre os órgãos arbitrais e os do Poder Judiciário. Assim o Poder Judiciário teria a competência para conceder ou não a medida de urgência. Em caso de concessão da medida de urgência, esta medida poderia posteriormente vir a ser confirmada, modificada ou cessada pelo árbitro, tão logo tenha sido solucionado o impasse que impedia a instauração do juízo arbitral.

Para os referidos autores (2012, p.328), justificando a relativização do princípio Compétence-Compétence:

Importa ressaltar que a competência provisória do órgão do Poder Judiciário decorre da impossibilidade da pretensão cautelar ser apreciada pelo órgáo jurisdicional competente (árbitro), diante de fato que impede o acesso da parte ao juízo arbitral. Parte do princípio em que assegurar a utilidade e a efetividade do resultado a ser buscada no processo principal e, portanto, garantir a realização dos escopos da jurisdição é, nas situaçôes descritas, reputada mais importante do que a aplicação dos princípios processuais que norteiam a atribuição de competência.

Neste mesmo sentido, aplicando a relativização do princípio, é o Acórdão proferido pelo Superior Tribunal de Justiça (STJ) no julgamento do Recurso Especial 2011/0240991-9, ocorrido em 12/06/2012:

2. Na pendência da constituiçáo do Tribunal Arbitral, admite-se que a parte se socorra do Poder Judiciário, por intermédio de medida de natureza cautelar, para assegurar o resultado útil da arbitragem.

3. Superadas as circunstâncias temporárias que justificavam a intervenção contingencial do Poder Judiciário e considerando que a celebração 
do compromisso arbitral implica, como regra, a derrogação da jurisdição estatal, os autos devem ser prontamente encaminhados ao juízo arbitral, para que este assuma o processamento da ação e, se for o caso, reaprecie a tutela conferida, mantendo, alterando ou revogando a respectiva decisão.

4. Em situações nas quais o juízo arbitral esteja momentaneamente impedido de se manifestar, desatende-se provisoriamente as regras de competência, submetendo-se o pedido de tutela cautelar ao juízo estatal; mas essa competência é precária e não se prorroga, subsistindo apenas para a análise do pedido liminar.

Em outros países também se verificam casos em que se opera, por vezes, uma relativização na aplicação do princípio Compétence-Compétence, tal como ocorre no Brasil.

Tiburcio (2007, p. 424-435), por exemplo, comenta julgado do Supremo Tribunal de Justiça Federal da Alemanha em que ocorre uma relativização da aplicação do princípio Compétence-Compétence, ao permitir que os órgãos do Poder Judiciário conheçam de matéria relativa à existência e validade da convenção de arbitragem sem respeitar a ordem cronológica estabelecida na aplicação do princípio. A questão apreciada pela corte alemã e comentada pela autora diz respeito à convenção de arbitragem inserida em contrato de consumo.

\section{Recentes Precedentes Brasileiros Reconhecem a Aplicação do Princípio Competénce-Competénce em Matéria Comercial}

Ao contrário do que ocorre com as "matérias sensíveis", tratadas no capítulo antecedente, a jurisprudência brasileira vem dando provas de firme respaldo ao princípio Compétence-Compétence em casos de arbitragem empresarial. Além de decisóes mais antigas, merece destaque, por ser extremamente recente, decisão do Tribunal de Justiça do Estado do Rio de Janeiró ${ }^{4}$.

O litígio ocorreu entre duas empresas que haviam contratado a compra e venda de um prédio na regiấo central do Rio de Janeiro, contendo obrigaçóes contratuais conexas, como a construção de um edifício garagem e o "retrofit" do prédio principal, além do estabelecimento de um prêmio comercial cujo pagamento estaria vinculado ao sucesso na locação do prédio.

A cláusula compromissória firmada entre as partes estava assim redigida:

6.1. Exceção feita àquelas relativas ao pagamento do preço e sua exigibilidade, todas as demais questôes relativas à interpretação e

4 TJRJ. Agravo de Instrumento n. 0054241-31.2014.8.19.0000. Décima primeira Câmara Cível. Agravante: BRPR XXVII Empreendimentos. Agravado: Manchester Patrimonial S/A. Relator: Des. Fernando Cerqueira Chagas, julgado em 28 de janeiro de 2015. 
ao descumprimento das obrigaçóes previstas nesta escritura serão submetidas à arbitragem, (...)

Como houve desacordo entre as partes sobre a exigibilidade do aludido prêmio comercial, uma das partes procurou o Poder Judiciário para resolver o litígio. O juiz togado considerou-se competente para julgar a matéria, afastando a competência dos árbitros.

Como a cláusula compromissória excluía a competência dos árbitros somente para as questóes relativas ao pagamento do preço e havia fundada dúvida sobre a possibilidade do prêmio comercial integrar o conceito de preço, a outra parte recorreu da decisão do juiz estatal, alegando que a primazia temporal sobre a matéria seria obrigatoriamente dos árbitros.

O Tribunal de Justiça do Rio de Janeiro deu provimento ao recurso, tendo como ratio decidendi exatamente o princípio Compétence-Compétence. Colhe-se do voto do Desembargador relator:

As dificuldades surgem quando, como no presente caso, a cláusula é redigida de forma dúbia quanto aos limites da convenção de arbitragem, cabendo se indagar se o Judiciário deve intervir antes do árbitro e, interpretando as vontades das partes, decidir se devem se submeter à arbitragem ou ao foro de eleição.

Rodrigo Garcia da Fonseca, em O Princípio da Competência-Competência na Arbitragem, Revista de Arbitragem e Mediação, SP, n. 9, p. 291, 2007, afirma:

“... em qualquer situaçáo em que o ataque à convençáo de arbitragem dependa de produçáo de prova que já náo fora previamente constituída, ou de decisáo acerca de matéria complexa, razoavelmente discutivel, deve-se prestigiar a arbitragem, aplicando-se a regra de precedência temporal decorrente do princípio competência-competência, pois como náo se pode nunca deixar de repetir, 'é do árbitro o benefício da dúvida', sem prejuizo do controle judicial posterior da sua decisáo."

Ora, a questão acerca da natureza do "prêmio", ou seja, se constitui preço ou não, considerados os termos do contrato firmado entre as partes, requer um esforço de exegese, constituindo questáo complexa e da qual se podem extrair diferentes interpretaçôes com fundamentos razoáveis.

Por conseguinte, reputa-se como impositivo que o juiz se abstenha de conhecer da questão da competência antes que o árbitro se pronuncie sobre a sua própria competência.

A decisão do Tribunal de Justiça do Rio de Janeiro é digna de aplausos e pode ser considerada mais um passo importante em uma tendência que já se encontrava 
em outros acórdãos, alguns explicitamente citados pelo desembargador relator, como se nota de excerto do voto,

Logo, cabe ao árbitro decidir sobre a sua própria jurisdição, tendo sido consagrado o entendimento da existência de hierarquia cronológica entre o árbitro e o juiz togado, por força da qual o árbitro é quem decide, em primeiro lugar, a respeito de sua competência para conhecer acerca de determinada controvérsia.

Vale conferir a orientação jurisprudencial do STJ:

(...)

1.- Tratando-se de jurisdiçóes concorrentes, a estrangeira e a nacional, em que discutida a mesma matéria, isto é, a validade de cláusula arbitral constante de contrato celebrado no exterior sob expressa regência da legislação estrangeira, prevalece a sentença que primeiro transitou em julgado, no caso a sentença estrangeira.

2.- Conclusão, ademais, que preserva a opção pela solução arbitral, expressamente avençada pelas partes.

3.- Ante a cláusula arbitral, de rigor a submissáo da alegaçáo de nulidade primeiramente ante o próprio tribunal arbitral, como resulta de sentença estrangeira homologanda, que atende ao princípio “Kompetenz Kompetentz", sob pena de abrir-se larga porta à judicializaçáo nacional estatal prematura, à só manifestação unilateral de vontade de uma das partes, que, em consequência, teria o poder de, tão somente "ad proprium nutum", frustrar a arbitragem avençada.

4.- Impossibilidade de homologação de parte da sentença estrangeira que determina a desistência, sob sanção, de ação anulatória movida no Brasil, dada a preservaçáo da concorrência de jurisdição.

5.- Sentença estrangeira parcialmente homologada, para a submissão das partes ao procedimento arbitral, afastada, contudo, a determinaçáo de desistência, sob pena de multa, da ação movida no Brasil.

SEC .854/EX, Rel. Ministro MASSAMI UYEDA, Rel. p/ Acórdão Ministro SIDNEI BENETI, CORTE ESPECIAL. julgado em 16/10/2013, DJe 07/11/2013 (grifo nosso)

Como assinala o E. Ministro Luiz Fux em seu voto no AgRg na SEC 854 (2005/0123803):

Sobressai dos comentários de Pedro A. Bastista Martins acerca da aplicação da cláusula compromissória, in verbis:

"Em havendo controvérsia quanto à submissão da matéria à arbitragem, seja por falha ou dupla interpretaçâo da cláusula compromissória, a tendência moderna dos doutrinadores e das cortes estatais é a de conferir ao órgão arbitral competência para a apreciaçâo e o julgamento da questão. 
Impera o princípio 'na dúvida pró arbitragem." (In, Aspectos Fundamentais da Lei de Arbitragem, de autoria de Pedro A. Batista Martins, Selma M. Ferreira Lemes e Carlos Alberto Carmona, Editora Forense, Páginas 213/220).

É importante apontar que no Brasil o STJ reconhece a possibilidade de existência do conflito positivo de competência entre a jurisdição arbitral e a do Poder Judiciário, bem como a competência do STJ para decidir sobre a referida matéria. Nesse sentido, há precedente do próprio STJ reconhecendo a competência do árbitro para conceder medida cautelar de arrolamento de bens. Tal decisão também implicou o reconhecimento judicial da arbitragem como jurisdição. ${ }^{5}$

Até mesmo nos casos em que grandes empresas não estabelecem relação de direito civil ou comercial entre elas, mas, ao contrário, com pessoas físicas, o Poder Judiciário prestigia o princípio Compétence-Compétence. Exemplo paradigmático desse entendimento encontra-se no julgamento do Recurso Especial 1.278.8526.

Nesse caso, o juiz da causa havia aplicado o princípio Compétence-Compétence corretamente, mas o Tribunal de Justiça do Estado de Minas Gerais entendeu que a análise da validade da cláusula compromissória pode ser exercida pelo juiz estatal quando o procedimento arbitral ainda náo tiver iniciado. O Ministro relator proveu o recurso que contestava a decisão do Tribunal de Justiça, realizando correta distinção entre os conflitos gerados por cláusulas vazias, que reclamam a utilização o art. $7^{\circ}$ da lei de arbitragem brasileira, como já analisado no segundo capítulo do presente trabalho, e as situaçóes envolvendo cláusulas compromissórias cheias. Nesse último caso, a primazia para a análise da validade e eficácia da convenção de arbitragem é dos árbitros, devendo o Poder Judiciário realizar eventual análise posterior, como colhe-se de trecho da ementa do julgado,

3. De fato, é certa a coexistência das competências dos juízos arbitral e togado relativamente às questóes inerentes à existência, validade, extensão e eficácia da convenção de arbitragem. Em verdade - excluindo-se a hipótese de cláusula compromissória patológica ("em branco") -, o que se nota é uma alternância de competência entre os referidos órgáos, porquanto a ostentam em momentos procedimentais distintos, ou seja, a possibilidade de atuação do Poder Judiciário é possível tão somente após a prolação da sentença arbitral, nos termos dos arts. 32, I e 33 da Lei de Arbitragem. 4. No caso dos autos, desponta inconteste a eleição da Câmara de Arbitragem Empresarial Brasil (CAMARB) como tribunal arbitral para dirimir

5 STJ - Conflito de Competência (CC) no 111230 - 2a Seção - Relatora: Nancy Andrighi - Autor: C.E.B Ltda, Réu: S. E Ltda - julgado em 08/05/2013 - votação por maioria.

6 STJ- Recurso Especial n. 1.278. 852/MG. Relator: Luis Felipe Salomão - Recorrente: Samarco Mineração S/A, Recorrido: Jerson Valadares da Cruz. Julgado em 21/05/2013 
as questóes oriundas do acordo celebrado, o que aponta forçosamente para a competência exclusiva desse órgão relativamente à análise da validade da cláusula arbitral, impondo-se ao Poder Judiciário a extinçâo do processo sem resoluçáo de mérito, consoante implementado de forma escorreita pelo magistrado de piso. Precedentes da Terceira Turma do STJ.

Isto posto, acredita-se que a jurisprudência brasileira, ressalvadas algumas exceçôes, prestigia o princípio Compétence-Compétence, mormente em casos envolvendo a arbitragem comercial, que usualmente se afastam das chamadas "matérias sensíveis".

\section{Conclusões}

Constatou-se uma salutar solidificação da jurisprudência brasileira no sentido de respaldar o princípio Compétence-Compétence na seara empresarial. Não há qualquer dúvida que o acórdấo mais longamente comentado, proferido recentemente pela $11^{\text {a }}$ Câmara Cível do TJRJ, encontra-se de acordo com a doutrina e a jurisprudência dominante nos tribunais estaduais e no STJ.

Os julgadores utilizam o raciocínio que é aceito pela jurisprudência nacional e estrangeira no que concerne à aplicaçáo do princípio Compétence-Compétence. Promovem a correta validação do duplo efeito decorrente da convenção de arbitragem válida ao reconhecer a jurisdição do árbitro para decidir sobre a sua própria jurisdição e ao impedir a jurisdição prematura dos órgãos do Poder Judiciário.

Os exemplos de julgados em que ocorrem as hipóteses de relativização na aplicação do princípio, por sua vez, são aplicados apenas em certas situaçóes pontuais, identificadas ao longo do texto e admitidos por parte da doutrina. Trata-se de casos específicos que não ameaçam, no Brasil, a aplicaçáo prevalente dos efeitos do Compétence-Compétence. A importância da jurisprudência dominante analisada é reafirmar a relevância do princípio Compétence-Compétence, previsto expressamente na Lei no 9307/96.

A atuaçáo ponderada dos órgáos do Poder Judiciário, nos moldes do julgado do Tribunal de Justiça do Rio de Janeiro, reconhecendo a supremacia do princípio Compétence-Compétence e promovendo o seu afastamento apenas em algumas poucas situaçôes específicas não gera qualquer insegurança para os que pretendem resolver os conflitos por meio da arbitragem.

Constata-se que os casos submetidos aos órgãos do Poder Judiciário, em que a jurisprudência se inclina pela relativização da aplicação do princípio Compétence-Compétence, ocorrem de forma cada vez mais rara e esporádica. Tal fato se deve, em princípio, a um maior desenvolvimento do conhecimento sobre a aplicação e a prática da arbitragem. Assim, também tornam-se raras e esporádicas as celebraçôes de cláusulas compromissórias 
vazias ou patológicas ou, ainda, das hipóteses de concessão de medidas de urgência em decorrência da impossibilidade de instauração rápida do juízo arbitral.

Nos casos dos conflitos relativos aos dissídios individuais trabalhistas e das relaçóes de consumo, a jurisprudência existente já é suficiente para que as partes ponderem, com um maior cuidado, sobre a pertinência ou não de celebrarem convenção de arbitragem (principalmente cláusula compromissória) atribuindo a competência aos árbitros para decidir sobre as referidas matérias.

\section{Referências}

BRASIL. TRIBUNAL REGIONAL FEDERAL (5. Região). Apelação cível no 42.441PE (94.05.01629-6). Apelante: Edilemos Mamede dos Santos e outros. Apelada: Escola Técnica Federal de Pernambuco. Relator: Juiz Nereu Santos. Recife, 4 de março de 1997.Disponível em: http//www.trf5.jus.br/cp/cp.do. Acesso em 25/05/2015.

BRASIL. SUPERIOR TRIBUNAL DE JUSTIÇ//A. R.Esp. 2011/0240991-9. Recorrente: Itarumã Participaçóes S/A. Recorrido: Participaçôes em Complexos Bioenergéticos S/A. Relatora: Nancy Andrighi. julgado 12/06/2012, votação unânime. Disponível em: http://www.stj.jus.br/SCON/jurisprudencia/doc.jsp?livre=arbitragem $+\& \& b=A C O R \& p=$ true $\& \mathrm{t}=\& \mathrm{l}=10 \& \mathrm{i}=64$. Acesso em 09/05/2015.

BRASIL. SUPERIOR TRIBUNAL DE JUSTIÇA.- Recurso Especial n. 1.278. 852/ MG. Recorrente: Samarco Mineração S/A. Recorrido: Jerson Valadares da Cruz. Relator: Luis Felipe Salomão. Julgado em 21/05/2013, votação por maioria. : http://www.stj.jus.br/SCON/jurisprudencia/toc.jsp?tipo_visualizacao=RESUMO\&livre=\%28\%22LUIS+FELIPE+SALOM\%C3O\%22\%29.min. \&proces$\mathrm{so}=1278852 \& \mathrm{~b}=\mathrm{ACOR} \&$ thesaurus=JURIDICO. Acesso em 05/05/2015.

BRASIL. SUPERIOR TRIBUNAL DE JUSTIÇA. CC no 111230. Autor: C.E.B Ltda. Réu: S. E Ltda. Relatora: Nancy Andrighi. Julgado em 08/05/2013, votação por maioria. Disponível em: http://www.stj.jus.br/SCON/jurisprudencia/doc. jsp?livre $=$ arbitragem + conflito + competencia $\& \& b=A C O R \& p=$ true $\& \mathrm{t}=\& \mathrm{l}=10 \& \mathrm{i}=7$. Acesso em 09/05/2015.

BRASIL. TRIBUNAL DE JUSTIÇA DO ESTADO DO RIO DE JANEIRO. Apelação Cível no 0007525-03.2011.8.19.0209. Disponível em: http://www1.tjrj.jus.br/ gedcacheweb/default.aspx?UZIP =1\&GEDID=000451E95371147157852CABD74476B90E91C503495F3139. Acesso em 01/03/2015.

BRASIL. TRIBUNAL DE JUSTIÇA DO ESTADO DO RIO DE JANEIRO. Apelação Cível no 0026771-82.2011.8.19.0209. Disponível em: http://www1.tjrj.jus.br/ gedcacheweb/default.aspx?UZIP=1\&GEDID=0004B5289E53C150AE75A8CEB48130301621 C50346630E1B. Acesso em 01/03/2015. 
BRASIL. TRIBUNAL DE JUSTIÇA DO ESTADO DO RIO DE JANEIRO. Agravo de Instrumento n. 0054241-31.2014.8.19.0000. Agravante: BRPR XXVII Empreendimentos. Agravado: Manchester Patrimonial S/A. Relator: Des. Fernando Cerqueira Chagas, julgado em 28 de janeiro de 2015. Disponível em http://www1.tjrj. jus.br/gedcacheweb/default.aspx?UZIP=1\&GEDID=000494E10C28576322AAE0FF87D5ED025686C50349624E24. Acesso em 22/05/2015.

BRASIL. TRIBUNAL DE JUSTIÇA DO RIO GRANDE DO SUL. Ag.Instr. no 70051678332. Disponível em: http://www1.tjrs.jus.br/site_php/consulta/consulta_processo.php?nome_comarca $=$ Tribunal+de+Justi\%E7a\&versao=\&versao_fonetica $=1 \&$ tipo=1\&id_comarca $=700 \&$ num_processo_mask=70051678332\&num_ processo $=70051678332 \& \operatorname{codEmenta}=5140420 \&$ temInt Teor $=$ true. Acesso em $01 / 03 / 2015$.

BRASIL. TRIBUNAL SUPERIOR DO TRABALHO. R.R. n $\mathrm{n}^{\mathrm{o}}$ 10190060.2009.5.02.0024. Disponível em: https://aplicacao5.tst.jus.br/consultaProcessual $/$ resumoForm.do?consulta $=1 \&$ numeroInt=185958\&anoInt=2012. Acesso em $01 / 03 / 2015$.

BRASIL. TRIBUNAL SUPERIOR DO TRABALHO. A.I.R.R. n n 44534.2012.5.01.0005. Disponível em: https://aplicacao5.tst.jus.br/consultaProcessual $/$ resumoForm.do? consulta $=1 \&$ numeroInt=185397\&anoInt=2014. Acesso em $01 / 03 / 2015$.

CÂMARA DE COMÉRCIO INTERNACIONAL. Estatística. Disponível em: http:// www.iccwbo.org/Products-and-Services/Arbitration-and-ADR/Arbitration/Introduction-to-ICC-Arbitration/Statistics/. Acesso em 09/05/2015.

CARMONA, Carlos Alberto. Arbitragem e processo. 3a ed., São Paulo: Atlas, 2009.

COMISSÁO DAS NAÇÓES UNIDAS PARA O DIREITO DO COMÉRCIO INTERNACIONAL (UNCITRAL). Lei modelo sobre arbitragem comercial internacional. Disponível em: http://www.cbar.org.br/leis_intern_arquivos/Lei_Modelo_Uncitral_traduzida_e_revisada_versao_final.pdf. Acesso em 09/05/2015.

FLUJA, Vicente Guzmán. Artículo 22. Potestad de los árbitros para decidir sobre su competencia. In. VILAR, Silvia Barona (Coordinadora). Comentarios a la ley de arbitraje. Madrid : Thomson/Civitas, 2004, p. 805-831.

FOUCHARD, Ph.; GAILLARD, E.; GOLDMAN, B. Traité de l'arbitrage commercial international. Paris : Litec, 1996.

GUERREIRO, José Alexandre Tavares. Fundamentos da arbitragem do comércio internacional. São Paulo : Saraiva, 1993.

HEINTZMAN, Thomas G. What are the limits of competence-competence for arbitral tribunals. Publicado em 03/06/2012. Disponível em: http://www.constructionlaw- 
canada.com/arbitration/what-are-the-limits-of-competence-competence-for-arbitral-tribunals/. Acesso em 28 de fevereiro de 2015.

LEE, João Bosco. Arbitragem comercial internacional nos países do Mercosul. Curitiba: Juruá, 2002.

LEMES, Selma. Arbitragem em números - Números mostram a maior aceitação da arbitragem no Brasil. Revista Consultor Jurídico. Publicado em 10/04/2014. Disponível em: http://www.conjur.com.br/2014-abr-10/selma-lemes-numeros-mostram-maior -aceitacao-arbitragem-brasil. Acesso em 09/05/2015.

PITOMBO, Eleonora C. Os efeitos da convenção de arbitragem - adoção do princípio kompetenz-kompetenz no Brasil. In: LEMES, Selma Ferreira; CARMONA, Carlos Alberto; MARTINS, Pedro Batista. Arbitragem - estudos em homenagem ao prof. Guido Fernanndo Silva Soares, in memoriam. São Paulo: Atlas, 2007, p. 326-338.

REDFERN, Alan.; HUNTER, Martin. Law and practice of international commercial arbitration. Londres:Sweet\&Maxwell, 1999.

RECHSTEINER, Beat Walter. Arbitragem privada internacional no Brasil. 2a ed., São Paulo: Editora Revista dos Tribunais, 2001.

SANTOS. Ricardo Soares Stersi dos. Noçóes Gerais da Arbitragem. Florianópolis: Fundação Boiteux, 2004.

TIBURCIO, Carmen. O princípio da Kompetenz-Kompetenz revisto pelo Supremo Tribunal Federal de Justiça alemão. In: LEMES, Selma Ferreira; CARMONA, Carlos Alberto; MARTINS, Pedro Batista. Arbitragem - estudos em homenagem ao prof. Guido Fernanndo Silva Soares, in memoriam. São Paulo: Atlas, 2007, p. 425-435.

. Arbitragem no Brasil: Panorama dos Últimos 15 Anos. In: LEMES, Selma Ferreira; BARLBINO, Inez (coord). Arbitragem: Temas Contemporâneos. São Paulo: Quartier Latin, 2012, p. 75-101. 